\title{
Tobacco related resources on the Internet
}

\author{
Mark Hayman
}

The Internet is a valuable resource for obtaining tobacco related information. One article has briefly explored some of the sites that are available. ${ }^{1}$ The following provides an outline of some of the major categories of tobacco related information currently available on the internet. The knowledge base relating to tobacco control is large and rapidly evolving. The Internet provides an invaluable resource for current information and a history of tobacco control programmes and activities from many parts of the world. Many of the listed sites provide extensive links to other related resources.

Lycos (http://lycos.cs.cmu.edu/) and Yahoo (http://www.yahoo.com/) are two search tools available on the internet that provide a fast, efficient way of searching for information on particular topics. Because the internet is constantly evolving, the links to resources provided below may change. Search tools are a reliable way of locating information and discovering new resources (such as new tobacco company advertisements).

\section{Tobacco control resources}

There are numerous tobacco control organisations providing chronological histories of their own tobacco control activities, local legislative developments, updates on current legislative efforts, and links to other tobacco resources on the internet. Several health organisations provide information on tobacco and health.

Action on Smoking and Health (ASH) (USA) http://www.setinc.com/ash/intro.html.

Provides a chronology of tobacco control developments and legislation within the United States, campaign information, access to the bimonthly ASH review, and more.

The militant anti-smokers' homepage

http://www.mbnet.mb.ca/ cmckin/smoke.html

Essentially just a collection of links to other tobacco related sites. Less impressive than it sounds.

\section{NICNET}

Sydney University,

http://hinet.medlib.arizona.edu/ pubhlth/tobac.htm

mustralia
usyd.edu.au
M Hayman,
medical student

1 Leischow SJ. Nicotine and tobacco hit the internet. Society for Research on Nicotine and Tobacco Newsletter 1995;
1 (3): 4-5.

Provides as excellent resources guide to the Arizona anti-smoking organisation.

Tobacco in Australia: facts and issues

http://www.peg.apc.org/ vshp/

Full text of the 415 page opus written by Stephen Woodward, Noni Walker, and Margaret Winstanley covering everything you'd want to know about tobacco in Australia. The preface, acknowledgments and the introduction can be accessed without charge. Subscription to the complete book is \$AUD60. Subscribe from the home page or contact Quit Victoria by phone $+61-3-96637777$ or fax +61-3-9663 7761 .

\section{Tobacco BBS}

http://www.dx.com/tobacco/

Provides a comprehensive resources guide, links to "Tobacco Daily", an update on US tobacco control activities.

\section{INFACT}

http://sunsite.unc.edu/boutell/infact/ infact.html/

An anti-smoking activist group based in the United States providing comprehensive updates on their Philip Morris boycott campaign, legislative developments, and news updates.

\section{American Medical Association}

http://www.ama-assn.org

Provides access to abstracts of $\mathcal{F} A M A$, and full text of the 19 July 1995 articles on tobacco, based on an analysis of the Brown and Williamson documents.

\section{Canadian Medical Association}

http://hpbl.hwc.ca:8400/

Information from the National Clearinghouse on Tobacco and Health in Canada.

\section{The Canadian Supreme Court case} http://Fox.NSTN.Ca:80/ ncth2/

Provides a chronological outline of developments in tobacco control in Canada, and an account of the RJR McDonald $v$ Canada case on the Tobacco Control Act, with the full Supreme Court findings.

The Master Anti-Smoking Page http://www.autonomy.com/smoke.htm 
This page is dedicated to helping people quit smoking and to helping people, especially the young, to not start.

See also: http://www.ozlink.com/yinyang/ This is a commercial site for a stop-smoking programme and contains a wealth of information about what smoking does to the body.

Tobac Talk

This is a listserver site for people involved in tobacco control. To subscribe, send an email message to listserv@arizvml.ccit.arizona.edu and in the body of your message type: SUBSCRIBE TOBACTALK 〈YOUR NAME >

\section{Tools for Tobacco Educators}

http://world.std.com/ batteryb/

Provides a sample collection of counter-advertising posters, cartoons, billboards and signs depicting the "smooth reaper", a parody on the Joe Camel and Grim Reaper advertising characters.

\section{Smoking From All Sides}

http://www.cs.brown.edu/people/lsh/

smoking.html

A comprehensive collection of links to pro and anti-smoking sites and resources.

\section{The Web of Addictions}

http://www.well.com/user/woa

A well formatted and constructed collection of resources and accurate information about alcohol and other drug addictions. Provided as a resource for teachers, students and others needing factual information about abused drugs.

\section{Government information resources and libraries}

There are various government institutions that provide tobacco related statistics, health information and reports on tobacco, and updates on tobacco related legislation and programmes. These are United States, Canadian, and World Health Organisation (WHO) resources.

\section{US Department of Health and Human Services \\ http://www.os.dhhs.gov}

Centers for Disease Control and Prevention http://www.cdc.gov

Publishes the Morbidity and Mortality Weekly Review.

US Environmental Protection Agency and references to reports of the US Surgeon General

http://www.epa.gov
US Food and Drug Administration (FDA)

http://www.fda.gov/bbs/tobacinfo/

juristoc.html

Information on the role of the FDA, in-

formation on tobacco and youth and full text of the recent FDA tobacco regulation proposal.

\section{WHO}

http://www.who.ch/programmes/

psa/psahome.html

Provides extensive listings of publications and programmes relating to tobacco control programmes being supported or coordinated by the WHO.

International Union Against Cancer (UICC) http://www-uicc.who.ch/

Provides access for authorised persons to the GLOBALink international tobacco control network.

International Organisation for Standardisation Online

(http://www.iso.ch/cate/65160.html)

Tobacco, tobacco products and related equipment. The ISO standards are used for tar and nicotine content testing of cigarettes.

\section{Australian Legislation at The NSW Law Foundation \\ http://www.fl.asn.org}

Provides public access to an extensive range of Australian Federal and State legislation, regulations and cases. Provides ready and up-todate access to tobacco specific legislation.

\section{Commercial tobacco services \\ STAR Tobacco}

http://www.startobacco.com

The first US domestic tobacco retailer advertising on the internet. It maintains a site with pictures of cigarette packages and ordering information.

\section{TaxFree Cigarettes}

http://www.woodtech.com/cigarettes/

A mail order service for discount cigarettes for "major US and Canadian cigarette brands".

Bokor Mas kreteks

http://www/public.iastate.edu/ aciek/bokormas.html

An Indonesian "fine clove cigarette" manufacturer, providing the company mission statement, product information and a product ordering service. All the products are said to be high quality and low price.

Smokin' Joe's Cigar retailer http://www.charm.net/ ibc/smokin/

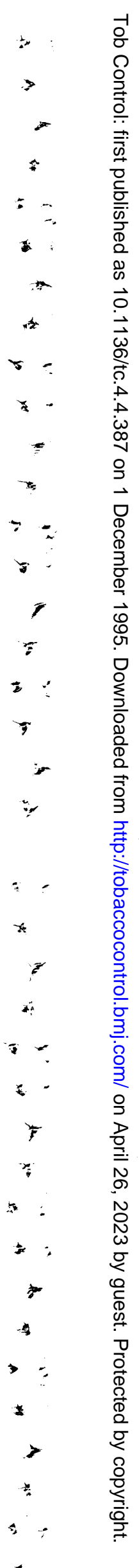


The Tobacconist

http://www.law.vill.edu/

kmortens/humidor/

A magazine about cigars and cigar smoking plus extensive links to a large list of cigar manufacturers and cigar product lists. Includes a link to the Internet Smoke Shop (http://www.apk.net/smoke/) which "will ship single cigars almost anywhere in the world with no minimum purchase requirements" and offer steeply discounted boxes and cigar of the month programs.

Fuji Publishing Group Cigar Page http://www.netins.net/showcase/fujicig/ Provides a range of links to cigar distributors, smokers news groups, and other smoking related sites.

Japan Tobacco Products

Museum, and more. English Home Page at: http://www.jtnet.ad.jp/WWW/Island/

Welcome.html

Jack Cannon (US), a computer expert and tobacco control advocate who monitors media coverage of tobacco issues, has also suggested the following sites:

http://cigarworld.com (Macanudo cigar company) - this is one of many cigar sites; it is alright but the links above through Fuji and The Tobacconist will take you to this and more. http://www.jtnet.ad.jp/Island/Welcome.htm (Japan Tobacco Home Page)-mostly in Japanese-some of the photos are good but otherwise only valuable if there is a Japanese readership.

http://woodtech.com/cigarettes/ (David Glenn Enterprises) - already included above as TaxFree cigarettes - duplicate.

The home page of a tobacco industry law firm http://www2.interpath.net/wcsr/ (Womble Carlyle Sandridge \& Rice, PLLC)

Internal tobacco company documents There have been various previously confidential company documents that have been made available publicly on the internet. These provide valuable insight and information on previously unconfirmed activities and programmes of some of the major US tobacco companies.

Brown and Williamson documents http://www.library.ucsf.edu/tobacco/bw.html Available from University of California, San Francisco Library, Tobacco Control Archives. A large searchable collection of internal company documents revealing the company objectives and strategies over the last 30 years.

Rf Reynolds documents

http://www.gate.net/ jcannon/

tobacco.html
Three internal memos indicating that the company deliberately targeted teenage smokers in marketing efforts, specifically tailored new brands for the youth market, and emphasised the need to establish brands for the $14-18$ year old age group.

\section{Tobacco Victims Association}

http://www.gate.net/ jcannon/tvaonline.html

Operates under the umbrella of STAT (Stop

Teenage Addiction to Tobacco).

Philip Morris documents

http://www.library.ucsf.edu/

$\mathrm{kr} / \mathrm{subs} /$ tobacco/pm.html

These were presented in US Congressional hearings in August 1995 and detailed the company's research projects into the effects of smoking and the pharmacology of nicotine in children and college students.

\section{Tobacco newsgroups}

Discussion groups for smokers, non-smokers, cigar and pipe smokers and people trying to quit.

- news :alt.smokers

- news :alt.support.non-smokers

- news :alt.smokers.cigars

- news :alt.smokers.pipes

- news:alt.support.stop-smoking

- http://www.ncl.ac.uk:80/ nnpb/ (a resource for smokers trying to quit)

\section{Miscellaneous}

Shadowland

http://magi.com/ shadow/

shadowland.html

A collection of photographs of women smoking. Celebrities and nude photos are shown.

Movie lists

http://www.cs.brown.edu/people/lsh/stories A list of smoking scenes in a large collection of US and other films. There is also a listing of a large collection of films made specifically about smoking.

Electronic published newspapers, magazines, and journals

Several of the above links provide collections of tobacco related news stories published in the media. There are also various major US and international newspapers and magazines published online that provide access to current news stories, including news relating to tobacco.

Jack Cannon has also provided the following sites :

- http://www.ash.org/ash/ (US ASH) already included in the first section above

- http://www.bcm.tmc.edu/doc/ (Doctors Ought to Care (DOC)) 
http://www.wln.com/ washdoc/ (Washington DOC)

- http://www.sirius.com/ anr (Americans for Nonsmokers' Rights (ANR))

- http://fox.nstn.ca/ ncth2/ccshccts.html - NCTH Canada is already included; these are subdirectories

- http://fox.nstn.ca/ ncth2/ncdo.html ditto

- http://world.std.com/ batteryb/ (BADvertising Institute) - included under "tools for educators"

- http://sunsite.unc.edu/boutell/ infact/gasp/gasp.html
- http://www.xmission.com/ seer/AIRSPACE/airspace.html

- http://www.xmission.com/ seer/AIRSPACE/news0295.html

- http://www.ncl.ac.uk:80/ nnpb/

- http://www.cts.com:80/ habtsmrt/

- http://www.thegroup.net/ppm/ ppmhome.html

- gopher://gopher.igc.apc.org:7003/11/ news/tob/1

(Tobacco News)

- gopher://gopher.igc.apc.org:7003/11/ news/tob/

(Tobacco News)

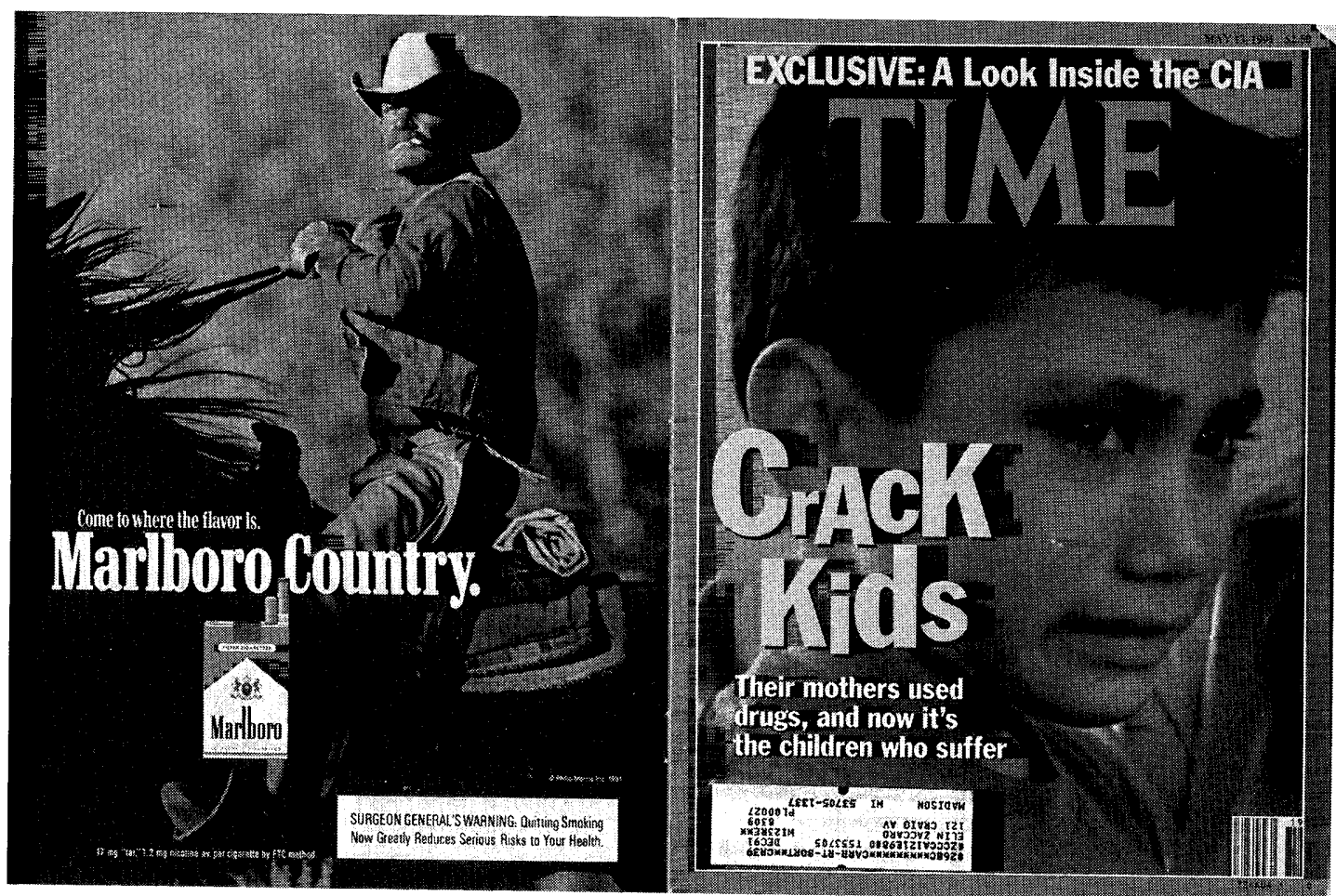

Submitted by Daniel J Zaccaro. 